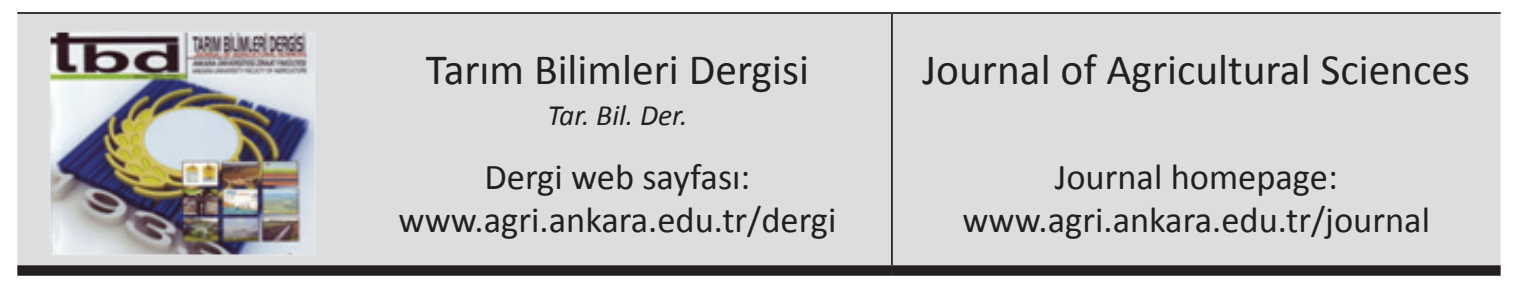

\title{
Effects of Thidiazuron and Activated Charcoal on in vitro Shoot Proliferation and Rooting of Myrtle (Myrtus communis L.)
}

\author{
Bekir ŞAN ${ }^{\mathrm{a}}$, Yaşar KARAKURT ${ }^{\mathrm{b}}$, Fatma DÖNMEZ ${ }^{\mathrm{a}}$ \\ ${ }^{a}$ Süleyman Demirel University, Faculty of Agriculture, Department of Horticulture, 32260, Isparta, TURKEY \\ ${ }^{\boldsymbol{b}}$ Süleyman Demirel University, Faculty of Agriculture, Department of Agricultural Biotechnology, 32260, Isparta, TURKEY
}

\section{ARTICAL INFO}

Research Article DOI: 10.1501/Tarimbil 0000001319

Corresponding Author: Bekir ŞAN, E-mail: bekirsan@sdu.edu.tr, Tel: +90 (246) 2118532

Received: 20 December 2013, Received in revised form: 3 March 2014, Accepted: 3 July 2014

\begin{abstract}
In this study, a micropropagation approach was developed for a commercially important myrtle clone 'Aş1 Mersin' in Turkey. The effects of different concentrations of thidiazuron (TDZ), 6-benzylaminopurine (BAP) and naphthalene acetic acid (NAA) on shoot formation and the effect of activated charcoal on rooting were studied. The most of the shoots were obtained on Murashige and Skoog (MS) medium containing $0.3 \mathrm{mg} \mathrm{L}^{-1} \mathrm{TDZ}+0.1 \mathrm{mg} \mathrm{L}^{-1} \mathrm{NAA}$ in the $1^{\text {st }}$ subculture (3.8 shoot), and from MS with $0.3 \mathrm{mg} \mathrm{L}^{-1} \mathrm{TDZ}+0.01 \mathrm{mg} \mathrm{L}^{-1} \mathrm{NAA}$ in the $2^{\text {nd }}$ subculture $(4.0$ shoot). The explants were rooted in $1 / 2 \mathrm{MS}$ containing indole-3-butyric acid (IBA), NAA and activated charcoal (AC). IBA applications induced more rooting than NAA. The medium supplemented with $1.0 \mathrm{mg} \mathrm{L}^{-1} \mathrm{IBA}+2.0 \mathrm{~g} \mathrm{~L}^{-1} \mathrm{AC}$ resulted in the highest rooting ratio $(80 \%)$. Addition of $\mathrm{AC}$ into the medium resulted in slight increase in the rooting ratio, significant increase in shoot length, and reduced darkening in the rooting area. Acclimatization was successful for $86 \%$ of the rooted plants.

Keywords: Myrtle; Proliferation; Activated charcoal; Thidiazuron; Acclimatization
\end{abstract}

\section{Thidiazuron ve Aktif Kömürün Mersinin (Myrtus communis L.) in vitro Sürgün Proliferasyonu ve Köklenmesi Üzerine Etkileri}

\section{ESER BİLGISİ}

Araștırma Makalesi

Sorumlu yazar: Bekir ŞAN, E-posta: bekirsan@sdu.edu.tr, Tel: +90 (246) 2118532

Geliş tarihi: 20 Aralık 2013, Düzeltmelerin gelişi: 3 Mart 2014, Kabul: 3 Temmuz 2014

\section{ÖZET}

Çalışmada, Mersin bitkisinin ticari öneme sahip “Aşı Mersin” klonu için bir mikro çoğaltım yöntemi geliştirilmiştir. $\mathrm{Bu}$ amaçla farklı konsantrasyonlarda thidiazuron (TDZ), 6-benzil amino pürin (BAP) ve naftalin asetik asit'in (NAA) sürgün proliferasyonu ve aktif karbonun $(\mathrm{AK})$ köklenme üzerine etkileri belirlenmiştir. En yüksek sürgün sayıları 1. alt kültürde 3.8 adet ile $0.3 \mathrm{mg} \mathrm{L}^{-1} \mathrm{TDZ}+0.1 \mathrm{mg} \mathrm{L}^{-1} \mathrm{NAA}$ içeren Murashige ve Skoog (MS) ortamından elde edilirken, 2. alt kültürde 4.0 adet ile $0.3 \mathrm{mg} \mathrm{L}^{-1} \mathrm{TDZ}+0.01 \mathrm{mg} \mathrm{L}^{-1} \mathrm{NAA}$ içeren $\mathrm{MS}$ ortamından elde edilmiştir. Ín vitro sürgünler indole-3-butyric acid (IBA), NAA ve aktif kömür içeren $1 \frac{1}{2} \mathrm{MS}$ ortamında köklendirilmiştir. IBA uygulamalarının NAA 
uygulamalarına göre köklenmeyi daha fazla uyardığı belirlenmiştir. İçinde $1.0 \mathrm{mg} \mathrm{L}^{-1} \mathrm{IBA}+2.0 \mathrm{~g} \mathrm{~L}^{-1} \mathrm{AC}_{\text {bulunan }}$ $1 / 2$ MS ortamı en yüksek köklenme oranını (\% 80) vermiştir. Ortama AC eklenmesi köklenme oranını nispeten ve sürgün uzunluğunu önemli derecede arttırmış ve kök bölgesindeki kararmayı ise azaltmıştır. Köklenmiş bitkilerin \% 86'sı dış koşullara başarılı bir şekilde alıştırılmıştır.

Anahtar Kelimeler: Mersin; Proliferasyon; Aktif kömür; Thidiazuron; Dış koşullara alıştırma

(C) Ankara Üniversitesi Ziraat Fakültesi

\section{Introduction}

Myrtle is included in the Myrtus species of Myrtaceae family which is a large family containing approximately 132 genera and 5671 species (Govaerts et al 2008). Most of them grow in the tropical and subtropical regions of South America and Australia. The Mediterranean myrtle (Myrtus communis L.) is economically the most important species among the evergreen myrtles (Baytop 1997). The fruits and leaves of myrtles are used for anti-genotoxic, anti-mutagenic, antiseptic, antiinflammatory purposes and the treatment of internal and topical infections (Bonjar 2004; Hayder et al 2004). Its essential oils can be used for the production of natural medicines and its leaves can be consumed as tea (Flamini et al 2004; Ogur, 1994). The fruits and leaves of wild myrtles are picked and evaluated by the growers who grow the promising genotypes with superior fruit quality, and then sold at local bazaars in Turkey.

The widespread use of myrtle has resulted in an increase in its production. However, the information about its reproduction is limited. Klein et al (2000) stated that, application of indole-3-butyric acid (IBA) promoted rooting upto $70 \%$ on cuttings of 'Rehovot' and 'Tzfat' myrtle cultivars taken between December and March. There are also studies on in vitro propagation of myrtle. BAP was used as the cytokinin in all micropropagation studies (Nobre 1994; Parra \& AmoMarco 1998). However, none of the studies investigated the effects of thidiazuron, another type of cytokinin, on the micropropagation of myrtle.

Several plant species including myrtle secrete phenolic substances during in vitro culture and these phenolic substances inhibit the development of the plant (Ruffoni et al 2003; Yağcı Tüzün et al 2013). Activated charcoal (AC) has been widely used in the micropropagation studies that the secretion of phenolics is encountered. AC has also been used for seed germination, anther culture, somatic embryogenesis and in vitro rooting studies (Blanc et al 1999; Kitsaki et al 2004; Laura et al 2006). At the rooting stage, $\mathrm{AC}$ delays the disintegration of the auxin added into the medium and positively affects plant development by adsorbing the inhibitors such as phenolic substances and abscisic acid (Thomas 2008). The plant growth regulators such as IBA and naphthalene acetic acid (NAA) were successfully used for the rooting of micro-cuttings in myrtle (Nobre 1994; Parra \& AmoMarco 1998). However, Ruffoni et al (2003) reported that the micro-shoots of myrtle released dark exudates from the explant base during in vitro culture. It is well known that phenolic substances secreted by plants cause the darkening of explants, the decrease in the rooting rate and the slowdown of development. Solving the problems regarding the micropropagation of myrtle may contribute to the plant production and availability.

In the present study, the effect of TDZ in MS (Murashige \& Skoog 1962) medium supplemented with NAA on shoot proliferation of myrtle clone "Aşı Mersin" was investigated and compared with BAP. The effect of AC in combination with IBA or NAA on in vitro rooting was also investigated.

\section{Material and Methods}

Explants of myrtle clone 'Aşı Mersin' (Myrtus communis L.), a commercially important and widely grown clone in Turkey were used as plant material. The shoot tips $(0.5-1 \mathrm{~cm})$ from approximately 25 
years old mature plants grown in Antalya, Turkey were used in the culture, and the culture was initiated in the first week of May as described by Scarpa et al (2000).

\subsection{Induction of proliferation}

For surface disinfection, the shoots were incubated in $70 \%$ ethanol for $1 \mathrm{~min}$ and then the explants were shaken in 3\% sodium hypochlorite solution containing one or two drops of Tween-20 for 10 minutes, and washed three times with sterile distilled water for 5 minutes. MS medium (Murashige \& Skoog 1962) containing $0.1 \mathrm{mg} \mathrm{L}^{-1} \mathrm{GA}_{3}, 6 \mathrm{~g} \mathrm{~L}^{-1}$ agar, $30 \mathrm{~g} \mathrm{~L}^{-1}$ sucrose and NAA $(0.01$ and $0.1 \mathrm{mg}$ $\left.\mathrm{L}^{-1}\right)$ as auxin supplemented with either TDZ (0.1, 0.3 and $\left.0.5 \mathrm{mg} \mathrm{L}^{-1}\right)$ or BAP $(0.5,1.0$ and $2.0 \mathrm{mg}$ $\left.\mathrm{L}^{-1}\right)$ as cytokinin were used to determine the optimal plant growth regulator combination for shoot proliferation. The MS medium without plant growth regulators served as control. The $\mathrm{pH}$ of the medium was adjusted to 5.7 before the addition of agar and sucrose. The media was autoclaved at $121{ }^{\circ} \mathrm{C}$ for 15 min and dispensed into erlenmayer flasks $(50 \mathrm{~mL}$ flask $\left.^{-1}\right)$. The explants were incubated in a growth chamber at $25 \pm 1{ }^{\circ} \mathrm{C}$ under 16 hour photoperiod provided by cool-white fluorescent lamps (140$150 \mu \mathrm{mol} \mathrm{m} \mathrm{m}^{-2} \mathrm{~s}^{-1}$ ) at the micropropagation stage. The explants were sub-cultured twice for a period of 4 weeks, and shoot number and shoot length per explant were determined at the end of each subculture.

\subsection{Induction of rooting}

In order to root the in vitro shoots, the plantlets were cultured in $1 / 2 \mathrm{MS}$ medium containing $6 \mathrm{~g} \mathrm{~L}^{-1}$ agar and $20 \mathrm{~g} \mathrm{~L}^{-1}$ sucrose, and 0, 0.5, 1.0, 2.0 and $4.0 \mathrm{mg} \mathrm{L}^{-1}$ IBA or NAA alone or in combination with $2.0 \mathrm{~g} \mathrm{~L}^{-1}$ AC. The explants were incubated for 1 week at $25 \pm$ $1{ }^{\circ} \mathrm{C}$ in the dark, and then they were transferred into a growth chamber and incubated there for 3 weeks at $25 \pm 1{ }^{\circ} \mathrm{C}$ under 16 hours photoperiod provided by cool-white fluorescent lamps (140-150 $\mu \mathrm{mol} \mathrm{m}^{-2}$ $\left.\mathrm{s}^{-1}\right)$. At the end of 4 weeks, the rooting ratio (\%), root number and shoot length of the explants were determined.

\subsection{Acclimatization}

For acclimatization studies, approximately 150 micro shoots were planted into the $1 / 2 \mathrm{MS}$ medium containing $1.0 \mathrm{mg} \mathrm{L}^{-1} \mathrm{IBA}+2.0 \mathrm{~g} \mathrm{~L}^{-1} \mathrm{AC}$ which provided the highest rooting. Then, 100 healthy plants with root lengths of $1 \mathrm{~cm}$ were acclimatized to outdoor conditions by planting into the pots containing a mixture of peat + perlite $(2: 1)$. The plants were covered with a polyethylene covering and the relative humidity of the atmosphere inside the covering was reduced slowly by opening holes every day. The coverings were removed after 10 days.

\subsection{Statistical analysis}

Completely randomized design was used in in vitro proliferation and rooting experiments with 3 replications and 15 plants per replication. The data were subjected to the analyses of variance (ANOVA) at $\mathrm{P} \leq 0.05$ using MINITAB statistical software (MINITAB Inc., UK). Means were separated by Duncan's multiple range test at $\mathrm{P} \leq$ 0.05 . The percent data were transformed into arcsin angle values prior to analyses.

\section{Results and Discussion}

\subsection{Induction of proliferation}

In the first subculture, $0.3 \mathrm{mg} \mathrm{L}^{-1} \mathrm{TDZ}+0.1 \mathrm{mg}$ $\mathrm{L}^{-1}$ NAA treatment produced the highest number of shoots $(\mathrm{P}<0.05)$ while there was no difference among the others. In the second subculture, $0.3 \mathrm{mg}$ $\mathrm{L}^{-1} \mathrm{TDZ}$ in combination with 0.1 or $0.01 \mathrm{mg} \mathrm{L}^{-1} \mathrm{NAA}$ were significantly better $(\mathrm{P}<0.05)$ for proliferation than the rest of the treatments with the exception of $0.5 \mathrm{mg} \mathrm{L}^{-1} \mathrm{TDZ}$ treatments (Table 1; Figure 1). Applications of BAP were not significantly different from the control in terms of shoot number. In general, shoot lengths did not differ significantly among the treatments. We found that TDZ was more effective than BAP for proliferation. There have been studies regarding the effects of BAP as a cytokinin on the micropropagation of myrtle. Grigoriadou and Leventakis (2000) obtained the best propagation ( 3 shoots per explant) from MS 
medium containing $3 \mu \mathrm{M} \mathrm{BAP}+0.3 \mu \mathrm{M} \mathrm{GA}_{3}+$ $0.05 \mu \mathrm{M}$ NAA in the micropropagation of myrtle. Moreover, Parra \& Amo-Marco (1998) obtained better results with a total of 38.5 shoots per explant at the end of 8 weeks using $1 \mathrm{mg} \mathrm{L}^{-1} \mathrm{BAP}$ in MS medium. To date, the highest number of shoots per explant (34.8) at the end of a month's culture was reported by Scarpa et al (2000) who used MS medium supplemented with $2 \mathrm{mg} \mathrm{L}^{-1} \mathrm{BAP}+0.2$ $\mathrm{mg} \mathrm{L}^{-1}$ NAA which might be resulted from the use of a different genotype. At the micropropagation stages, cytokinins are one of the most important components affecting the success ratio. San et al (2009), reported that the medium with both TDZ and BAP was more effective in the propagation of jujube as compared to the media containing only TDZ or BAP alone. We used both BAP and TDZ as source of cytokinin in the experiments. However, we obtained better results from TDZ treatments as compared to BAP treatments (Table 1). To our knowledge, this is the first report on the effects of $\mathrm{TDZ}$ on in vitro propagation of myrtle.

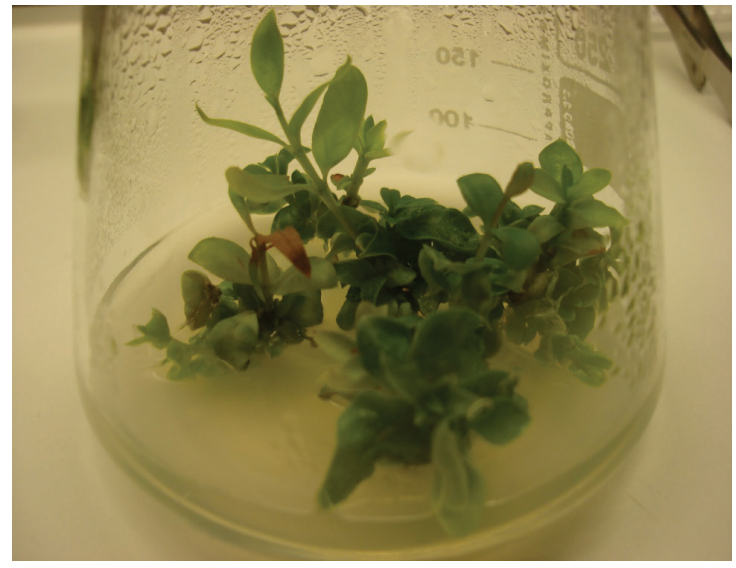

Figure 1- In vitro proliferation of myrtle on MS medium containing $0.3 \mathrm{mg} \mathrm{L}^{-1} \mathrm{TDZ}+0.1 \mathrm{mg} \mathrm{L}^{-1} \mathrm{NAA}$ Şekil 1- Mersinin $0.3 \mathrm{mg} \mathrm{L}^{-1} \mathrm{TDZ}+0.1 \mathrm{mg} \mathrm{L}^{-1} \mathrm{NAA}$ içeren MS ortamında in vitro çoğaltılması

\subsection{Induction of rooting}

The effects of IBA, NAA and AC $\left(2.0 \mathrm{~g} \mathrm{~L}^{-1}\right)$ were determined in the rooting stage of the study. The treatment of $1.0 \mathrm{mg} \mathrm{L}^{-1} \mathrm{IBA}+2.0 \mathrm{~g} \mathrm{~L}^{-1} \mathrm{AC}$ resulted in the highest $(80 \%)$ rooting (Table 2 , Figure $2 a$ ). There

Table 1- In vitro proliferation of myrtle on MS medium containing plant growth regulators

Çizelge 1- Mersinin farklı büyümeyi düzenleyici maddeleri içeren MS ortamında in vitro çoğaltılması

\begin{tabular}{|c|c|c|c|c|}
\hline \multirow[b]{2}{*}{ Treatments* } & \multicolumn{2}{|c|}{ I. Subculture } & \multicolumn{2}{|c|}{ II. Subculture } \\
\hline & $\begin{array}{l}\text { Shoot number per } \\
\text { explant** }\end{array}$ & $\begin{array}{l}\text { Shoot length } \\
(\mathrm{cm}) * * *\end{array}$ & $\begin{array}{l}\text { Shoot number per } \\
\text { explant }^{* *}\end{array}$ & $\begin{array}{l}\text { Shoot length } \\
(\mathrm{cm}) * * *\end{array}$ \\
\hline Control & $1.27 \mathrm{~b}$ & 1.42 & $1.00 \mathrm{c}$ & 1.35 \\
\hline $0.1 \mathrm{mg} \mathrm{L}^{-1} \mathrm{TDZ}+0.01 \mathrm{mg} \mathrm{L}^{-1} \mathrm{NAA}$ & $2.53 \mathrm{~b}$ & 1.65 & $2.38 \mathrm{~b}$ & 1.68 \\
\hline $0.1 \mathrm{mg} \mathrm{L}^{-1} \mathrm{TDZ}+0.1 \mathrm{mg} \mathrm{L}^{-1} \mathrm{NAA}$ & $1.95 \mathrm{~b}$ & 1.85 & $1.67 \mathrm{bc}$ & 1.54 \\
\hline $0.3 \mathrm{mg} \mathrm{L}^{-1} \mathrm{TDZ}+0.01 \mathrm{mg} \mathrm{L}^{-1} \mathrm{NAA}$ & $2.40 \mathrm{~b}$ & 2.08 & $4.00 \mathrm{a}$ & 1.53 \\
\hline $0.3 \mathrm{mg} \mathrm{L}^{-1} \mathrm{TDZ}+0.1 \mathrm{mg} \mathrm{L}^{-1} \mathrm{NAA}$ & $3.80 \mathrm{a}$ & 1.75 & $3.87 \mathrm{a}$ & 1.58 \\
\hline $0.5 \mathrm{mg} \mathrm{L}^{-1} \mathrm{TDZ}+0.01 \mathrm{mg} \mathrm{L}^{-1} \mathrm{NAA}$ & $2.48 \mathrm{~b}$ & 1.55 & $3.10 \mathrm{ab}$ & 1.65 \\
\hline $0.5 \mathrm{mg} \mathrm{L}^{-1} \mathrm{TDZ}+0.1 \mathrm{mg} \mathrm{L}^{-1} \mathrm{NAA}$ & $2.52 \mathrm{~b}$ & 1.62 & $3.05 \mathrm{ab}$ & 1.57 \\
\hline $0.5 \mathrm{mg} \mathrm{L}^{-1} \mathrm{BAP}+0.01 \mathrm{mg} \mathrm{L}^{-1} \mathrm{NAA}$ & $2.35 \mathrm{~b}$ & 1.57 & $1.60 \mathrm{bc}$ & 1.55 \\
\hline $0.5 \mathrm{mg} \mathrm{L}^{-1} \mathrm{BAP}+0.1 \mathrm{mg} \mathrm{L}^{-1} \mathrm{NAA}$ & $1.67 \mathrm{~b}$ & 1.59 & $1.07 \mathrm{bc}$ & 1.46 \\
\hline $1.0 \mathrm{mg} \mathrm{L}^{-1} \mathrm{BAP}+0.01 \mathrm{mg} \mathrm{L}^{-1} \mathrm{NAA}$ & $2.27 \mathrm{~b}$ & 1.53 & $1.73 \mathrm{bc}$ & 1.28 \\
\hline $1.0 \mathrm{mg} \mathrm{L}^{-1} \mathrm{BAP}+0.1 \mathrm{mg} \mathrm{L}^{-1} \mathrm{NAA}$ & $2.00 \mathrm{~b}$ & 1.61 & $1.40 \mathrm{bc}$ & 1.46 \\
\hline $2.0 \mathrm{mg} \mathrm{L}^{-1} \mathrm{BAP}+0.01 \mathrm{mg} \mathrm{L}^{-1} \mathrm{NAA}$ & $2.13 \mathrm{~b}$ & 1.29 & $1.73 \mathrm{bc}$ & 1.35 \\
\hline $2.0 \mathrm{mg} \mathrm{L}^{-1} \mathrm{BAP}+0.1 \mathrm{mg} \mathrm{L}^{-1} \mathrm{NAA}$ & $1.53 \mathrm{~b}$ & 1.62 & $1.20 \mathrm{bc}$ & 1.41 \\
\hline
\end{tabular}

*, $\mathrm{GA}_{3}$ at $0.1 \mathrm{mg} \mathrm{L}^{-1}$ was added to all treatments; ${ }^{* *}$, different letters in the same column indicate significant difference among the means at $\mathrm{P}<0.05$; ***, non-significant 
were no significant differences among $0.5,1.0$ or 2 $\mathrm{mg} \mathrm{L}^{-1}$ IBA or $0.5,1.0,2.0$ or $4.0 \mathrm{mg} \mathrm{L}^{-1} \mathrm{IBA}+2.0$ $\mathrm{g} \mathrm{L}^{-1} \mathrm{AC}$. In general, root numbers changed between 1.2 and 2.8 per explant, but differences among the treatments were insignificant. It is known that both genotype and growth regulators significantly affect rooting in myrtle. Ruffoni et al (2003) obtained 45$50 \%$ rooting in myrtle clones PA2, DCCOD 1 and AR6 in which IAA and IBA were used. Hatzilazarou et al (2003) reported clonal differences in rooting that $96 \%$ of microshoots of myrtle clone-A rooted on WPM medium containing $0.5 \mathrm{mg} \mathrm{L}^{-1}$ IBA while $100 \%$ of microshoots of myrtle clone-B rooted on the same medium but containing $1.0 \mathrm{mg} \mathrm{L}^{-1}$ IAA. In support of our findings, a $70 \%$ rooting ratio was obtained from the MS medium containing $1 \mathrm{mg} \mathrm{L}^{-1}$ IBA (Grigoriadou \& Leventakis 2000). However, we have observed darkening on the explant's base and an unhealthy shoot development when shoots were rooted without AC (Figure $2 b$ ) possibly due to the release of dark exudates from the explant's base (Ruffoni et al 2003). With the use of AC, darkening appeared to be reduced (Figure 2c). Likewise, in other species such as Zingiber officinale and Taxus mairei, addition of AC into the medium prevented the darkening on the explants (Chang et al 2001; Guo et al 2007). It is known that in some plants, certain physiological defects such as growth deficiency and darkening occur because of the excretion of certain inhibitors such as phenolics. Adding AC into the medium was reported to remove dangerous effects of the substances synthesized by plants by adsorbing (Thomas 2008). Previous studies reported that the use of $\mathrm{AC}$ either alone or in combination with auxin significantly stimulated rooting (Yang et al 2006) and reduced the callus formation (Agrawal et al 2002). However, we did not observe increased rooting percentage $\%$ (NSD), and callus formation on the rooting area of shoots in the present study (Table 2). Effects of AC on the rooting of the myrtle microshoots were not previously known.

We have also measured shoot lengths of the explants during in vitro rooting experiment. The data showed significant differences in shoot lengths of the explants which ranged from 1.6 to $4.2 \mathrm{~cm}$ (Table 2).

Table 2- The in vitro rooting of myrtle on $1 / 2 \mathrm{MS}$ medium supplemented with IBA, NAA and $2 \mathrm{~g} \mathrm{~L}^{-1}$ AC

Çizelge 2- Mersinin IBA, NAA ve $2 \mathrm{~g} L^{-1}$ AC içeren $1 / 2$ MS ortamında in vitro köklendirilmesi

\begin{tabular}{|c|c|c|c|}
\hline Treatments & Rooting (\%)* & Root number** & Shoot length $(\mathrm{cm}) *$ \\
\hline $1 / 2$ MS Medium & $0 \quad 1$ & - & $1.8 \mathrm{c}$ \\
\hline $1 / 2 \mathrm{MS}$ Medium $+0.5 \mathrm{mg} \mathrm{L}^{-1} \mathrm{IBA}$ & $66.7 \mathrm{abc}$ & 2.1 & $2.0 \mathrm{c}$ \\
\hline $1 / 2 \mathrm{MS}$ Medium $+1.0 \mathrm{mg} \mathrm{L}^{-1} \mathrm{IBA}$ & $60.0 \mathrm{abc}$ & 2.2 & $2.2 \mathrm{c}$ \\
\hline $1 / 2 \mathrm{MS}$ Medium $+2.0 \mathrm{mg} \mathrm{L}^{-1} \mathrm{IBA}$ & $53.3 \mathrm{abcd}$ & 2.8 & $2.3 \mathrm{c}$ \\
\hline $1 / 2 \mathrm{MS}$ Medium $+4.0 \mathrm{mg} \mathrm{L}^{-1} \mathrm{IBA}$ & $13.3 \mathrm{gh}$ & 2.5 & $1.6 \mathrm{c}$ \\
\hline $1 / 2 \mathrm{MS}$ Medium $+0.5 \mathrm{mg} \mathrm{L}^{-1} \mathrm{NAA}$ & $13.3 \mathrm{gh}$ & 1.5 & $1.8 \mathrm{c}$ \\
\hline $1 / 2 \mathrm{MS}$ Medium $+1.0 \mathrm{mg} \mathrm{L}^{-1} \mathrm{NAA}$ & 26.7 defg & 1.8 & $2.1 \mathrm{c}$ \\
\hline $1 / 2 \mathrm{MS}$ Medium $+2.0 \mathrm{mg} \mathrm{L}^{-1} \mathrm{NAA}$ & $20.0 \mathrm{efg}$ & 1.3 & $1.8 \mathrm{c}$ \\
\hline $1 / 2 \mathrm{MS}$ Medium $+4.0 \mathrm{mg} \mathrm{L}^{-1} \mathrm{NAA}$ & $20.0 \mathrm{fgh}$ & 1.2 & $1.9 \mathrm{c}$ \\
\hline $1 / 2 \mathrm{MS}$ Medium $+2.0 \mathrm{~g} \mathrm{~L}^{-1} \mathrm{AC}$ & $6.7 \mathrm{~h} 1$ & 2.1 & $3.2 \mathrm{~b}$ \\
\hline $1 / 2 \mathrm{MS}$ Medium $+0.5 \mathrm{mg} \mathrm{L}^{-1} \mathrm{IBA}+2.0 \mathrm{~g} \mathrm{~L}^{-1} \mathrm{AC}$ & $66.7 \mathrm{abc}$ & 2.6 & $3.6 \mathrm{ab}$ \\
\hline $1 / 2 \mathrm{MS}$ Medium $+1.0 \mathrm{mg} \mathrm{L}^{-1} \mathrm{IBA}+2.0 \mathrm{~g} \mathrm{~L}^{-1} \mathrm{AC}$ & 80.0 a & 1.9 & $4.2 \mathrm{a}$ \\
\hline $1 / 2 \mathrm{MS}$ Medium $+2.0 \mathrm{mg} \mathrm{L}^{-1} \mathrm{IBA}+2.0 \mathrm{~g} \mathrm{~L}^{-1} \mathrm{AC}$ & $73.3 \mathrm{ab}$ & 2.0 & $3.8 \mathrm{ab}$ \\
\hline $1 / 2 \mathrm{MS}$ Medium $+4.0 \mathrm{mg} \mathrm{L}^{-1} \mathrm{IBA}+2.0 \mathrm{~g} \mathrm{~L}^{-1} \mathrm{AC}$ & $53.3 \mathrm{abcd}$ & 1.5 & $3.9 \mathrm{ab}$ \\
\hline $1 / 2 \mathrm{MS}$ Medium $+0.5 \mathrm{mg} \mathrm{L}^{-1} \mathrm{NAA}+2.0 \mathrm{~g} \mathrm{~L}^{-1} \mathrm{AC}$ & 46.7 bcde & 1.3 & $3.4 \mathrm{ab}$ \\
\hline $1 / 2 \mathrm{MS}$ Medium $+1.0 \mathrm{mg} \mathrm{L}^{-1} \mathrm{NAA}+2.0 \mathrm{~g} \mathrm{~L}^{-1} \mathrm{AC}$ & 40.0 cdef & 1.5 & $3.2 \mathrm{~b}$ \\
\hline $1 / 2 \mathrm{MS}$ Medium $+2.0 \mathrm{mg} \mathrm{L}^{-1} \mathrm{NAA}+2.0 \mathrm{~g} \mathrm{~L}^{-1} \mathrm{AC}$ & 46.7 bcde & 1.8 & $3.2 \mathrm{~b}$ \\
\hline $1 / 2 \mathrm{MS}$ Medium $+4.0 \mathrm{mg} \mathrm{L}^{-1} \mathrm{NAA}+2.0 \mathrm{~g} \mathrm{~L}^{-1} \mathrm{AC}$ & 40.0 cdef & 2.2 & $3.3 \mathrm{~b}$ \\
\hline
\end{tabular}

*, different letters in the same column indicate significant difference among the means at $\mathrm{P}<0.05$; **, non-significant 


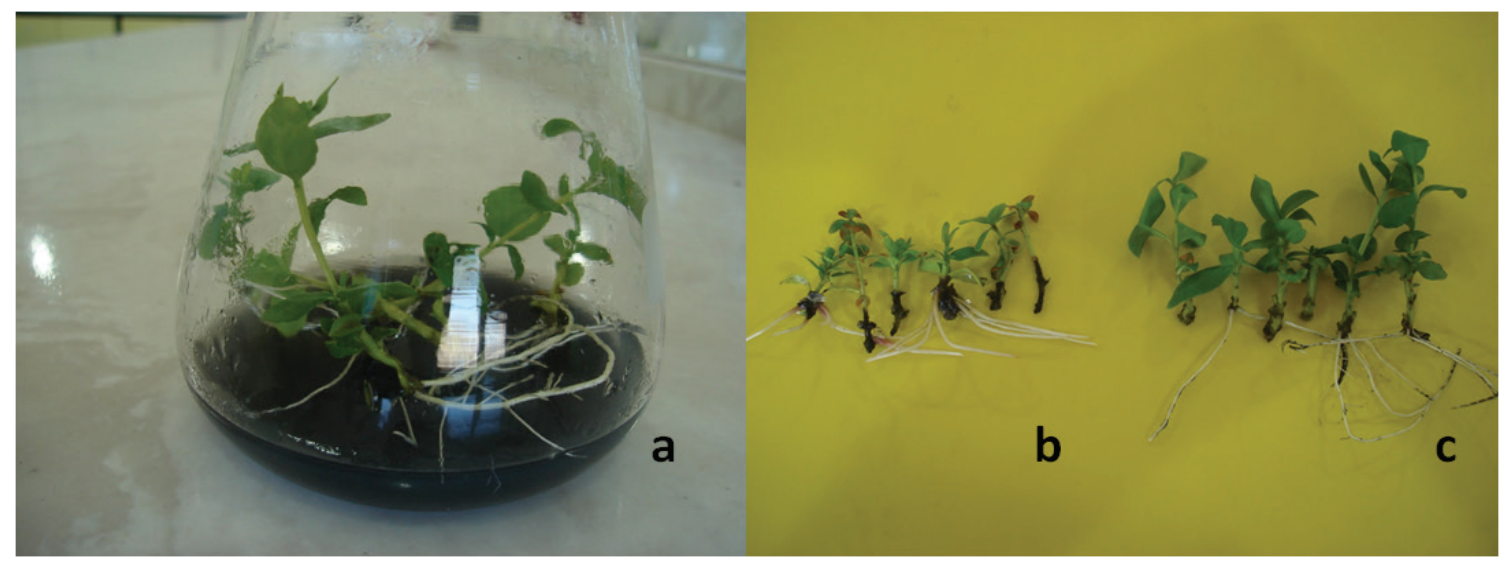

Figure 2- In vitro rooting of myrtles. a) microshoots rooted on $1 / 2 \mathrm{MS}$ medium containing 1 mg $\mathrm{L}^{-1}$ IBA +2 $\mathrm{g} \mathrm{L}^{-1} \mathrm{AC}$; b) unhealthy shoots and darkened area on the shoot base at treatments without AC; c) healthy shoots and little darkened area on the shoot base at treatments with $2 \mathrm{~g} \mathrm{~L}^{-1} \mathrm{AC}$

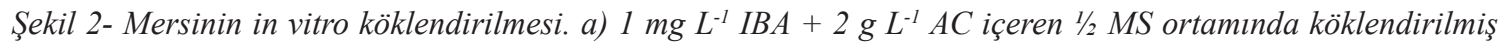
mikroçelikler; b) AC içermeyen ortamlarda mikroçeliklerin köklenme bölgesinde kararma ve săglıksız sürgünler; c) $2 \mathrm{~g} \mathrm{~L}^{-1}$ AC içeren ortamlarda köklenme bölgesindeki çok az kararma ve să̆lıklı sürgünler

The highest shoot length $(4.2 \mathrm{~cm})$ was obtained with $1.0 \mathrm{mg} \mathrm{L} \mathrm{L}^{-1} \mathrm{IBA}+2.0 \mathrm{~g} \mathrm{~L}^{-1}$ AC treatment. Adding $\mathrm{AC}$ into the rooting medium significantly increased shoot length from 1.94 to $3.53 \mathrm{~cm}$ on average (Table 2, Figure 2b, c). Similarly, Datta et al (2006) and Stojicic et al (2012) reported the lengthening effect of AC on internodes in plants.

\subsection{Acclimatization}

The plants with approximately $1 \mathrm{~cm}$ root length were planted into a growth medium of peat + perlite (2:1) mixture and acclimatized. The results showed that rooted shoots were successfully acclimatized $(86 \%)$ to outdoor conditions. Similar results were reported by Hatzilazarou et al (2003) who achieved over $97 \%$ of acclimatization in myrtles. One of the problems in myrtle micropropagation is the low success in acclimatization, because high doses of auxin in the rooting medium decrease the survival of plants at the stage of acclimatization (Welander 1983; Yepes \& Aldwinckle 1994). However, we did not observe any problem in the acclimatization stage with using $1 \mathrm{mg} \mathrm{L}^{-1}$ IBA concentration. Another factor complicating the acclimatization of plants is the root length. When roots exceed $1 \mathrm{~cm}$ length, callus formation at the rooting area increases and physiological defects develop on the roots (data not shown). Thus, our results showed that the plants should also be acclimatized to outdoor conditions as soon as they are rooted.

\section{Conclusions}

The medium containing TDZ was more effective in proliferation than BAP. For in vitro rooting of microshoots, $1 / 2$ MS medium supplemented with IBA was more effective than NAA. The addition of AC to the medium prevented the darkening of the explants, significantly increased shoot length and enhanced rooting. We suggest the use of MS medium with 0.3 $\mathrm{mg} \mathrm{L}^{-1} \mathrm{TDZ}+0.1$ or $0.01 \mathrm{mg} \mathrm{L}^{-1} \mathrm{NAA}$ for the in vitro proliferation, and, $1 / 2 \mathrm{MS}$ medium containing $1.0 \mathrm{mg}$ $\mathrm{L}^{-1} \mathrm{IBA}+2.0 \mathrm{~g} \mathrm{~L}^{-1} \mathrm{AC}$ for rooting of myrtle clone (Aşı Mersin). We also suggest acclimatization of in vitro plants as soon as they are rooted.

\section{References}

Agrawal V, Prakash S \& Gupta S C (2002). Effective protocol for in vitro shoot production through nodal explants of Simmondsia chinensis. Biologia Plantarum 45: 449-453 
Baytop T (1997). Türkçe bitki adları sözlüğü. Türk Dil Kurumu Yayınları, No: 578, Ankara, Turkey

Blanc G, Michaux-Ferriere N, Teisson C, Lardet L \& Carron M P (1999). Effects of carbohydrate addition on the induction of somatic embryogenesis in Hevea brasiliensis. Plant Cell Tissue and Organ Culture 56: $17-23$

Bonjar G H S (2004). Antibacterial screening of plants used in Iranian folkloric medicine. Fitoterapia 75: 231-235

Chang S H, Ho C K, Chen Z Z \& Tsay J Y (2001). Micropropagation of Taxus mairei from mature trees. Plant Cell Reports 20: 496-502

Datta M M, Majumder A \& Jha S (2006). Organogenesis and plant regeneration in Taxus wallichiana (Zucc.). Plant Cell Reports 25: 11-8

Flamini G, Cioni P L, Morelli I, Maccioni S \& Baldini R (2004). Phytochemical typologies in some populations of Myrtus communis L. on Caprione Promontory (East Liguria, Italy). Food Chemistry 85: 599-604

Govaerts R, Sobral M, Ashton P \& Barrie F (2008). World Checklist of Myrtaceae. The University of Chicago Press Books, ISBN: 9781842463918

Grigoriadou K \& Leventakis N (2000). Preliminary study on large scale in vitro propagation of Myrtus communis L. more options. Acta Horticulturae 541: 299-303

Guo Y, Bai J \& Zhang Z (2007). Plant regeneration from embryogenic suspension-derived protoplasts of ginger (Zingiber officinale Rosc.). Plant Cell Tissue and Organ Culture 89: 151-157

Hatzilazarou S, Grammaticos H, Economou A S, Rifaki N \& Ralli P (2003). Rooting in vitro and acclimatization of Myrtus communis microcuttings. Acta Horticulturae 616: 259-264

Hayder N, Abdelwahed A, Kilani S, Ben Ammar R, Mahmoud A, Ghedira K \& Chekir-Ghedira L (2004). Anti-genotoxic and free-radical scavenging activities of extracts from (Tunisian) Myrtus communis. Mutation Research 564: 89-95

Kitsaki C K, Zygouraki S, Ziobora M \& Kintzios S (2004). In vitro germination, protocorm formation and plantlet development of mature versus immature seeds from several Ophrys species (Orchidaceae). Plant Cell Reports 23: 284-290

Klein J D, Cohen S \& Hebbe Y (2000). Seasonal variation in rooting ability of myrtle (Myrtus communis L.) cuttings. Scientia Horticulturae-Amsterdam 83: 71-76

Laura M, Safaverdi G \& Allavena A (2006). Androgenetic plants of Anemone coronaria derived through anther culture. Plant Breeding 125: 629-634
Minitab Inc. 2000. Meet Minitab: Release 13 for Windows (B) 95/98/2000 and Windows NTTM. Minitab, USA

Murashige T \& Skoog F (1962). A revised medium for rapid growth and bioassays with tobacco tissue cultures. Physiologia Plantarum 15: 473-497

Nobre J (1994). In vitro shoot proliferation of Myrtus communis L. from field-grown plants. Scientia Horticulturae-Amsterdam 58: 253-258

Ogur R (1994). A Review about myrtle (Myrtus communis L.). Çevre Dergisi 10: 21-25 (article in Turkish with an abstract in English)

Para R \& AmoMarco J B (1998). Factor affecting in vitro shoot proliferation of Myrtus communis L. a comparison of adult and seedling material. In vitro Cellular and Developmental Biology-Pl 34: 104-107

Ruffoni B, Airo M, Fascella G, Mascarella C, Zizzo G \& Cervelli C (2003). Rooting and acclimatization of ornemental myrtle genotypes. Acta Horticulturae 616: $255-258$

San B, Yildirim A N \& Ecevit F M (2009). In vitro propagation of selected jujube (Zizyphus jujuba Mill.) genotypes, 33th Conference of the Agricultural Engineering, Board of the Hungarian Academy of Sciences

Scarpa G M, Milia M \& Satta M (2000). The influence of growth regulators on proliferation and rooting of in vitro propagated myrtle. Plant Cell Tissue and Organ Culture 62: 175-179

Stojicic D, Janosevic D, Uzelac B, Cokesa V \& Budimir S (2012). Micropropagation of Pinus peuce. Biologia Plantarum 56: 362-364

Thomas D T (2008). The role of activated charcoal in plant tissue culture. Biotechnology Advances 26: 618-631

Yağcı Tüzün C, Toker, M C \& Toker G (2013). Gentiana olivieri Griseb.'in Kallus Kültürlerinin Kurulması ve Sekonder Metabolitlerin Araştırılması. Tarım Bilimleri Dergisi - Journal of Agricultural Sciences, 19: $163-169$

Welander M (1983). In vitro rooting of the apple rootstock M26 in adult juvenile and growth phases and acclimatization of the plantlets. Physiologia Plantarum 58: 231-238

Yang L, Xu CJ, Hu G B \& Chen K S (2006). Direct shoot organogenesis and plant regeneration in Fortunella crassifolia. Biologia Plantarum 50: 729-732

Yepes L M \& Aldwinckle H S (1994). Micropropagation of thirteen Malus cultivars and rootstock and effect of antibiotics on proliferation. Plant Growth Regulation 15: $55-67$ 